\title{
SphK1 promotes development of non-small cell lung cancer through activation of STAT3
}

\author{
YUEFENG MA ${ }^{1}$, XIN XING ${ }^{2}$, RANRAN KONG ${ }^{1}$, CHUANTAO CHENG $^{3}$, SUONI LI $^{4}$, XIAOPING YANG ${ }^{1}$, \\ SHAOMIN LI ${ }^{1}$, FENG ZHAO ${ }^{1}$, LIANGZHANG SUN ${ }^{1}$ and GANG CAO ${ }^{5}$ \\ ${ }^{1}$ Department of Thoracic Surgery, ${ }^{2}$ Cadre Health Care Special Clinic, ${ }^{3}$ Department of Dermatology, \\ The Second Affiliated Hospital of Xi'an Jiaotong University, Xi'an, Shaanxi 710004; ${ }^{4}$ Department of \\ Internal Medicine, Shaanxi Provincial Cancer Hospital, Xi'an, Shaanxi 710061; 5 Department of General Surgery, \\ The Second Affiliated Hospital of Xi'an Jiaotong University, Xi'an, Shaanxi 710004, P.R. China
}

Received July 23, 2019; Accepted February 26, 2020

DOI: $10.3892 /$ ijmm.2020.4796

\begin{abstract}
Sphingosine kinase1 (SphK1) is an oncogenic enzyme that regulates tumor cell apoptosis, proliferation and survival. SphK1 has been reported to promote the development of non-small cell lung cancer (NSCLC), although the underlying mechanism remains to be determined. The aim of the present study was to examine the expression and function of SphK1 in NSCLC and to explore the underlying molecular mechanism. The results of the present study demonstrated that SphK1 expression was upregulated in NSCLC tissues and cell lines. Overexpression of SphK1 increased the proliferation and migration of NSCLC cells. Additionally, overexpression of SphK1 induced expression of antiapoptotic and migration-associated genes, such as Bcl-2, matrix metallopeptidase 2 and cyclin D1. Of note, signal transducer and activator of transcription 3 (STAT3) was also activated in the SphK1-overexpressing cells. By treatment with a STAT3 inhibitor, it was demonstrated that the SphK1-induced changes in expression of target genes, as well as the increase in proliferation and migration of NSCLC cells were mediated by STAT3. In conclusion, the effects of SphK1 overexpression on the development of NSCLC were demonstrated to be mediated by the activation of STAT3. These results suggested
\end{abstract}

Correspondence to: Professor Gang Cao, Department of General Surgery, The Second Affiliated Hospital of Xi'an Jiaotong University, 157 Xiwu Road, Xi'an, Shaanxi 710004, P.R. China E-mail: caogang_xa@126.com

Abbreviations: EMT, epithelial-to-mesenchymal transition; IL-6, interleukin 6; NC, negative control; NSCLC, non-small cell lung cancer; SCLC, small cell lung cancer; SH2, SRC homology 2; SphK1, sphingosine kinase 1; S1PR1, sphingosine-1-phosphate receptor 1; SRC homology 2; STAT3, signal transducer and activator of transcription 3 .

Key words: non-small cell lung cancer, SphK1, STAT3, cyclin D1, MMP2, Bcl-2, Bcl-xl that inhibition of the SphK1-STAT3 axis may be a potential strategy for the treatment of NSCLC.

\section{Introduction}

Lung cancer is one of most common malignancies in the world, and is major cause of cancer-associated death; it accounts for $11.6 \%$ of the total cancer cases, and the mortality accounts for $\sim 18.4 \%$ of all cancer deaths (1). There are two main subtypes of lung cancer, small cell lung cancer (SCLC) and non-small cell lung cancer (NSCLC); NSCLC accounts for $>85 \%$ of all lung cancer cases (2). Despite advances in diagnostic methods, patients with NSCLC are frequently diagnosed in the first instance with advanced stage lung cancer, which has a 5-year survival rate of $15.9 \%$ (3). Elucidating the mechanisms underlying the development and progression of NSCLC may result in improvements in diagnosis and treatment.

Sphingosine kinase ( $\mathrm{SphK})$ is a conserved lipid kinase that phosphorylates sphingosine into sphingosine 1-phosphate (S1P) (4). Two subtypes of SphKs are encoded in the human genome, SPHK1 and SPHK2, which regulate sphingolipid metabolism (5). A total of five evolutionarily conserved domains have been identified in all SphKs, and although the amino acid sequences are highly similar among the subtypes, the functions of the subtypes differ (6). S1P is a bioactive signaling molecule regulating cell health and certain diseases (7). Following intracellular formation by phosphorylation of SphKs, S1P is secreted and binds to its corresponding receptor (8). A total of five specific $G$ protein-coupled receptors, S1P receptor (S1PR)1-5, have been identified in mammalian cells (9). SphK1 has been reported to be highly expressed in multiple tumor types, such as breast and prostate cancer (10). Additionally, SphK1 is closely associated with signaling pathways involved in cell proliferation, migration, metastasis, epithelial-to-mesenchymal transition (EMT) and other cellular processes (11). High levels of SphK1 expression are associated with a less favorable outcome in patients with cancer; for example, increased expression of SphK1 in tumor cells is significantly associated with shorter survival in patients with metastatic melanoma (12). Signal transducer and activator of transcription (STAT) 3 is a transcription factor with significant 
roles in the regulation of multiple cellular activities (13). All STATs share similar domains, including the N-terminal domain, the central DNA-binding domain and the classic SRC homology 2 (SH2) domain (14). There are two phosphorylation sites in STAT3, and phosphorylation of Tyr705 is crucial for the activation of STAT3; once Tyr705 is phosphorylated by upstream kinases, STAT3 dimerizes through reciprocal interactions between the phosphotyrosine-SH2 domains, the dimer translocates to the nucleus and binds to the promoter regions of its target genes (15). Interleukin-6 (IL-6) is the most common factor that activates STAT3 (15). Numerous receptors have also been reported to activate STAT3, including epidermal growth factor receptor and vascular endothelial growth factor $(16,17)$. Activation of S1PR1 is considered to result in persistent activation of STAT3 (18). Using gene expression microarrays, STAT3 has been demonstrated to regulate $\sim 100$ target genes, using a threshold of a 1.5-fold increase in expression (19). Of note, enhanced expression of STAT3 target genes was observed in of several different types cancer. For example, early growth response-1 and JunB proto-oncogene are immediate response genes that activate the induction of the cell cycle (20). Cyclin D1 is also modulated by STAT3 and is considered to promote cell proliferation (21). Another target gene of STAT3 is matrix metallopeptidase 2 (MMP-2), which is involved in metastasis of cancer cells (22). Other factors, including Bcl-2, Bcl-xl and survivin, inhibit apoptosis (23). Therefore, the activation of STAT3 is associated with tumor progression.

SphK1 has been reported to be involved in the pathological processes associated with NSCLC by modulating certain signaling pathways. For example, SphK1 has been demonstrated to promote proliferation of NSCLC cells by modulating the downstream molecules in the PI3K/Akt pathway in vitro (24). SphK1 mediates the inhibitory effect of transforming growth factor $\beta$ on EMT in A549 cells (25). However, the mechanism underlying Sphk1 function remains to be fully elucidated, and there are multiple downstream target genes that have not been explored.

The present study hypothesized that SphK1 may promote the development of NSCLC and aimed to detect the expression of SphK1 in NSCLC, as well as to further examine the effects of SphK1 on NSCLC development in vitro and in vivo. The underlying molecular mechanism of SphK1 in NSCLC was also explored.

\section{Materials and methods}

Human tissue samples. Human NSCLC and SCLC tissues were obtained from 56 patients with NSCLC and 15 patients with SCLC treated by surgical resection at the Department of Thoracic surgery of The First Affiliated Hospital of Xi'an Jiaotong University (Xi'an, China) between May 2017 and May 2018. Tumor and adjacent non-cancerous tissues ( $3 \mathrm{~cm}$ away from the tumor) were collected. All procedures performed in the present study were approved by the Research Ethics Committee of The First Affiliated Hospital of Xi'an Jiaotong University, and written informed consent was obtained from all patients (approval no. 2019-1260). The tissue samples were immediately frozen in liquid nitrogen until total RNAs or proteins were extracted. The inclusion criteria for the study participants were as follows: i) Pathologically or cytologically confirmed NSCLC and SCLC; ii) resectable stage IA to IIIA iii) age $\geq 20$ and $\leq 75$ years; iv) at least one measurable lesion meeting the Response evaluation criteria in solid tumors version 1.1 (26); and v) written informed consent was provided. The exclusion criteria for the study participants were as follows: i) patients with interstitial lung disease or pulmonary fibrosis; ii) severe pleural effusion, peritoneal fluid and pericardial fluid; iii) superior vena cava syndrome; iv) patients with brain metastasis; v) uncontrollable diabetes mellitus and hypertension; vi) liver cirrhosis; vii) active heart disease; viii) pregnancy, possible pregnancy or breastfeeding; ix) tendency to bleed; and $x$ ) unresectable stage IIIB/IVA. The basic information of the enrolled patients is presented in Table I.

Cell culture. All cell lines were purchased from The Cell Bank of Type Culture Collection of the Chinese Academy of Sciences. Normal bronchial epithelial cells (16HBE), NSCLC cell lines H460 and A549, and SCLC cell lines H69 and H446 were cultured in DMEM (Gibco; Thermo Fishers Scientific, Inc.) supplemented with $10 \%$ FBS (Thermo Fisher Scientific, Inc.) in a humidified atmosphere with $5 \% \mathrm{CO}_{2}$ at $37^{\circ} \mathrm{C}$.

Reverse transcription-quantitative $(R T-q) P C R$. Total RNA was extracted from the frozen tissues and cells using the TRIzol $^{\circledR}$ reagent (Thermo Fisher Scientific, Inc.) according to the manufacturer's protocol. The isolated RNA was reverse transcribed into complementary DNA using a Reverse Transcription kit (Takara Bio, Inc.) at $42^{\circ} \mathrm{C}$ for $15 \mathrm{~min}$, and qPCR waas performed using a $20-\mu 1$ reaction system with $0.5 \mu \mathrm{l}$ sense and antisense primers, $50 \mathrm{ng} \mathrm{RT}$ product and $10 \mu 12 X$ SYBR TransStar Green PCR Super Mix in an IQ ${ }^{\mathrm{TM}} 5$ Real-Time PCR Detection System (Thermo Fisher Scientific, Inc.) to determine the expression levels of the target genes in SCLC and NSCLC tissues and cell lines. The thermocycling conditions were as follows: Denaturation at $95^{\circ} \mathrm{C}$ for $4 \mathrm{~min}$, followed by 40 cycles of denaturation at $95^{\circ} \mathrm{C}$ for $20 \mathrm{sec}$, annealing at $56^{\circ} \mathrm{C}$ for $30 \mathrm{sec}$ and extension at $72^{\circ} \mathrm{C}$ for $32 \mathrm{sec}$. Relative gene expression was determined using the $2^{-\Delta \Delta \mathrm{CT}}$ method (27), and GAPDH was used as the internal control. The sequences of the primers used are listed in Table II.

The Cancer Genome Atlas (TCGA) dataset analysis. The expression of SphK1 in patients with lung adenocarcinoma and control subjects from TCGA data was analyzed using an online tool GEPIA2 (http://gepia2.cancer-pku.cn/) (28). According to the website instructions, the results were analyzed using the 'Boxplot' function in the 'Expression DIY' section. Data from 483 patients with lung adenocarcinoma and 59 control subjects were compared.

Chemicals and antibodies. Antibodies against SphK1 (sc-365401), $\beta$-actin (sc-81178) and E-cadherin (sc-8426) were purchased from Santa Cruz Biotechnology, Inc. Antibodies against SphK2 (ab37977), Ki67 (ab15580), Bcl-2 (ab32124), Bcl-xL (ab32370) and cyclin D1 (ab16663) were purchased from Abcam. MMP-2 (87809S), phospho- (p-)STAT3 (9145S) and STAT3 (9139S) antibodies were purchased from Cell Signaling Technology, Inc. C188-9 (S8605) was purchased 
Table I. Basic characteristics of the enrolled patients.

\begin{tabular}{lcc}
\hline Characteristics & NSCLC & SCLC \\
\hline Age, years, median (range) & $53.5(28-76)$ & $50.4(35-71)$ \\
Sex, n (male/female) & $30 / 26$ & $8 / 7$ \\
Stage, n (\%) & & \\
IA-B & $10(14.1 \%)$ & $2(2.8 \%)$ \\
IIA-B & $29(40.8 \%)$ & $8(11.3 \%)$ \\
IIIA & $17(23.9 \%)$ & $5(7.1 \%)$ \\
\hline
\end{tabular}

NSCLC, non-small cell lung cancer; SCLC, small cell lung cancer.

Table II. Primer sequences.

\begin{tabular}{ll}
\hline Gene & \multicolumn{1}{c}{ Sequence $\left(5^{\prime} \rightarrow 3^{\prime}\right)$} \\
\hline GAPDH & F: GACCTGCCGTCTAGAAAAAC \\
& R: TTGAAGTCAGAGGAGACCAC \\
SphK1 & F: CTGTCACCCATGAACCTGCT \\
& R: TACAGGGAGGTAGGCCAGTC \\
Bcl-xL & F: AGACCCAGACCTTCCTCTTCT \\
& R: CCCGGTTGCTCTGAGACATTT \\
Bcl-2 & F: ATGTGTGTGGAGAGCGTCAACC \\
& R: TGAGCAGAGTCTTCAGAGACAGCC \\
MMP-2 & F: TACAGGATCATTGGCTACACACC \\
& R: GGTCACATCGCTCCAGACT \\
Cyclin D1 & F: GTGAAGTTCATTTCCAATCCGC \\
& R: GGGACATCACCCTCACTTAC
\end{tabular}

SphK1, sphingosine kinase 1; MMP-2, matrix metallopeptidase 2.

from Selleck Chemicals. The 3-diaminobenzidine (DAB) staining kit (cat. no. CW0125) was purchased from CWBio.

Transfection. The target genes were inserted into the pcDNA3 vector (OBiO Technology Corp., Ltd) to construct the plasmid. Plasmids containing the transcript for SphK1, SphK1 $1^{\mathrm{G} 82 \mathrm{D}}$ or an empty vector were purchased from OBiO Technology (Shanghai) Corp., Ltd. G82D mutation was selected as a negative control as it led to the loss of catalytical ability of SphK1 (29). A549 cells were transfected with $3 \mu$ g plasmids in one well of a 6-well plate using Lipofectamine ${ }^{\circledR} 2000$ (Thermo Fisher Scientific, Inc.) at room temperature when they reached $80 \%$ confluence. The cells were transfected for $36 \mathrm{~h}$ prior to use in subsequent experiments.

Colony formation. A549 cells transfected with SphK1, SphK $1^{\mathrm{G} 82 \mathrm{D}}$ or an empty vector were seeded into 6-well plates $\left(1 \times 10^{3}\right.$ cells/well) and cultured in complete medium at $37^{\circ} \mathrm{C}$ with $5 \% \mathrm{CO}_{2}$ for 2 weeks. When colonies were formed, the cells were fixed with methanol for $10 \mathrm{~min}$, followed by staining with $0.1 \%$ crystal violet (Beijing ComWin Biotech Co., Ltd.) for $5 \mathrm{~min}$ at room temperature. The stained colonies were counted using an E100 light microscope (Nikon Corporation). Clusters of $\geq 50$ cells were defined as a colony.
Lentiviral infection. SphK1 was inserted in BamHI/AgeI restriction sites of the lentiviral expression vector GV358, which was purchased from OBiO Technology (Shanghai) Corp., Ltd. When A549 cells reached 80\% confluence, they were transduced with the lentivirus using an Envirus ${ }^{\mathrm{TM}}$ virus infection enhancer solution (Engreen Biosystem Co., Ltd.) for $48 \mathrm{~h}$ at $37^{\circ} \mathrm{C}$ before use in subsequent experiments. The multiplicity of infection was 30 . The cells stably expressing SphK1 were used to establish the xenograft lung cancer model in nude mice.

Transwell invasion assay. The upper chamber of the Transwell inserts was pre-coated with Matrigel at room temperature for $1 \mathrm{~h}$. A total of $1 \times 10^{5}$ A549 cells were added to the upper chamber in $200 \mu \mathrm{l}$ serum-free medium (Corning, Inc.). A total of $800 \mu \mathrm{l}$ medium supplemented with $10 \%$ FBS was added to the lower chamber of each well. The cells that had invaded through the membrane after $24 \mathrm{~h}$ were fixed with methanol for $30 \mathrm{~min}$ and stained with $0.1 \%$ crystal violet for $20 \mathrm{~min}$ at room temperature. The stained cells were counted using an E100 light microscope (Nikon Corporation) with x 10 magnification in five randomly chosen fields.

Western blotting. A549 cells were washed with cold PBS and lysed using RIPA lysis buffer (Beyotime Institute of Biotechnology, Inc.) supplemented with protease inhibitors for $13 \mathrm{~min}$ on ice. Subsequently, the cells were centrifuged at $13,000 \mathrm{x}$ g for $15 \mathrm{~min}$ at $4^{\circ} \mathrm{C}$. The protein was quantified using a bicinchoninic acid assay, and $20 \mu \mathrm{g}$ protein per lane was loaded on a $10 \%$ SDS gel, resolved using SDS-PAGE and transferred to PVDF membranes (EMD Millipore). The membranes were blocked with $0.5 \%$ non-fat milk for $2 \mathrm{~h}$ at room temperature and incubated with the SphK1 (1:100), $\beta$-actin $(1: 1,000)$, E-cadherin (1:200), SphK2 (1:1,000), Bcl-2 (1:1,000), Bcl-xL (1:1,000), cyclin D1 (1:1,000), MMP-2 (1:1,000), phospho- (p-) STAT3 (1:500) and STAT3 (1:1,000) primary antibodies with gentle agitation at $4^{\circ} \mathrm{C}$ for $12 \mathrm{~h}$. Subsequently, the membranes were washed with TBS $+0.1 \%$ Tween-20 three times and incubated with horseradish peroxidase-conjugated goat anti-rabbit IgG H\&L (cat. no. as014) or goat anti-mouse IgG H\&L (cat. no. as003; 1:5,000; both from ABclonal Biotech Co., Ltd.) antibodies for $2 \mathrm{~h}$ at room temperature, and the signals were visualized using an enhanced chemiluminescence reagent (Thermo Fisher Scientific, Inc.). ImageJ version 1.4.7 (National Institutes of Health) was used for densitometry analysis.

MTT assay. A549 cells were plated in 96-well plates at the density of $5 \times 10^{4}$ cells/well. After transfection with SphK1 or SphK $1^{\mathrm{G} 82 \mathrm{D}}$ plasmid and treatment with a STAT3 inhibitor, $5 \mathrm{mg} / \mathrm{ml}$ MTT was added to each well for $5 \mathrm{~h}$. The medium was removed, and $100 \mu 1 \mathrm{DMSO}$ was added to each well to dissolve the formazan crystals. Cell viability was measured at 12,24 , 48 and $72 \mathrm{~h}$ after treatment. The absorbance was measured at $490 \mathrm{~nm}$ using a SpectraMax M2 microplate reader (Molecular Devices, LLC).

Immunohistochemistry. Tissues were sectioned into 5- $\mu \mathrm{m}$ slices. Antigen retrieval was performed using citric acid buffer under high pressure for $2 \mathrm{~min}$, and tissue sections were rehydrated using a graded series of ethanol $(100,95,85$ and 
$75 \%$ ), deparaffinized and heated in a microwave for $15 \mathrm{~min}$. To inactivate endogenous peroxidases, $3 \%$ hydrogen peroxide solution was added. Subsequently, slides were blocked in 5\% BSA (Sigma-Aldrich; Merck KGaA) in PBS for $1 \mathrm{~h}$, after which slides were incubated with the Ki67 antibody (1:50) overnight in a humidified chamber at $4^{\circ} \mathrm{C}$. The following day, the slides were washed with PBS, and the tissues were incubated with the horseradish peroxidase-conjugated goat anti-rabbit antibody (1:200; cat. no. ab205718; Abcam) at room temperature for $2 \mathrm{~h}$. Subsequently, the sections were stained with DAB and incubated with a streptavidin-biotin complex (P0615; Beyotime Institute of Biotechnology) for $30 \mathrm{~min}$ at $37^{\circ} \mathrm{C}$. Finally, the sections were rinsed with sterile water three times and analyzed using an E100 light microscope (Nikon Corporation) with x10 magnification in five randomly chosen fields.

BrdU staining and immunofluorescence. A549 cells were seeded onto coverslips (Thermo Fisher Scientific, Inc.) and transfected with SphK1 or SphK1 ${ }^{\mathrm{G} 82 \mathrm{D}}$ plasmids. Subsequently, the cells were incubated at room temperature with BrdU (cat. no. ST1056; Beyotime Institute of Biotechnology) for $1 \mathrm{~h}$ and with an anti-BrdU antibody (cat. no. A1482; ABclonal Biotech Co., Ltd.) according to the manufacturer's protocol. Fluorescence was observed using a Leica BMI-6000 confocal microscope with x10 magnification (Leica Microsystems, Ltd.).

Tumor xenografts in nude mice. For in vivo experiments, 6-week old male BALB/c nude mice were purchased from the Shanghai Experimental Animal Centre of the Chinese Academy of Sciences. Each mouse was subcutaneously injected in the flank with $1 \times 10^{7}$ A549 cells stably expressing SphK1 or the control lentivirus in $0.1 \mathrm{ml}$ PBS. Once tumors were established, mice were intraperitoneally injected with either DMSO or $100 \mathrm{mg} / \mathrm{kg} \mathrm{C188-9}$ five times a week. Tumors were measured every 3 days using calipers, and the volume was calculated as follows: Volume $=\left(\right.$ width $^{2} \mathrm{x}$ length $) / 2$. Mice in the control and treatment groups $(n=5$ per group) were sacrificed by cervical dislocation, and their neoplastic tissues were dissected for further analysis and weighed. The procedures performed on mice were approved by the Research Ethics Committee of The First Affiliated Hospital of Xi'an Jiaotong University (approval no. 2019-1261).

Statistical analysis. The data are presented as the mean \pm standard deviation of at least three repeats. SPSS 13.0 (SPSS, Inc.) was used for statistical analysis. Unpaired Student's t-test or one-way ANOVA followed by Tukey's post hoc test was used to compare the groups. $\mathrm{P}<0.05$ was considered to indicate a statistically significant difference.

\section{Results}

Expression levels of SphK1 and SphK2 are upregulated in NSCLC tissues and cell lines. The mRNA expression levels of SphK1 and SphK2 in clinical NSCLC and SCLC samples were assessed. Compared with the corresponding normal tissues, SphK1 mRNA expression was 2.63-fold higher, and SphK2 mRNA expression was 2.21-fold higher in NSCLC. In
SCLC, SphK1 mRNA expression was 2.35-fold higher, and that of SphK2 was 1.92-fold higher compared with the corresponding normal tissues (Fig. 1A-D). In addition, the protein expression levels of SphK1 and SphK2 were assessed. Similar to the mRNA results, the protein expression of SphK1 was 2.51-fold higher, and that of SphK2 was 1.82-fold higher in NSCLC compared with the corresponding normal tissues. In SCLC, Sphk1 protein level was 2.25-fold higher, and that of SphK2 was 1.67-fold higher compared with the corresponding normal tissues (Fig. 1E-H). Additionally, the mRNA and protein expression levels of SphK1 and SphK2 in NSCLC and SCLC cell lines were compared with those in the 16HBE cells. The results revealed that SphK1 mRNA expression was 2.78and 2.21-fold higher in the $\mathrm{H} 460$ and A549 cells, respectively, compared with the $16 \mathrm{HBE}$ cells. In addition, SphK2 mRNA expression was 2.35- and 1.73-fold higher in the H460 and A549 cells, respectively, compared with the $16 \mathrm{HBE}$ cells. SphK1 mRNA expression was 2.12- and 2.20-fold higher, and SphK2 expression was 1.85- and 1.36-fold higher in the H69 and H446 cells, respectively, compared with the 16HBE cells (Fig. 2A-D). The western blotring result demonstrated that SphK1 protein expression was 2.58- and 2.35-fold higher, and that of SphK2 was 1.81- and 1.85-fold higher in the H460 and A549 cells, respectively, compared with the 16HBE cells. SphK1 protein expression was 1.52- and 1.78-fold higher, and that of SphK2 was 1.62- and 1.27-fold higher in the H69 and $\mathrm{H} 446$ cells, respectively, compared with the $16 \mathrm{HBE}$ cells (Fig. 2E-H). Therefore, the expression of SphK1 was further analyzed between patients with lung adenocarcinoma and healthy controls in The Cancer Genome Atlas dataset. The result demonstrated that SphK1 expression was higher in patients with lung adenocarcinoma compared with the control group (Fig. S1). Thus, based on these results, the effects and mechanism of SphK1 in NSCLC were investigated.

SphK1 promotes the proliferation of NSCLC cells. To examine the role of SphK1 in the progression of NSCLC, SphK1 or SphK1 $1^{\mathrm{G} 82 \mathrm{D}}$ was overexpressed in A549 cells (30). Western blotting results confirmed the successful transfection of SphK1 (Fig. 3A). An MTT assay was used to analyze cell proliferation; the results demonstrated that overexpression of SphK1 in A549 cells increased cell proliferation, whereas transfection with SphK1 ${ }^{\mathrm{G} 82 \mathrm{D}}$ reduced cell proliferation compared with the control group (Fig. 3B). Cell viability was also measured after different durations $(12,24,48$ and $72 \mathrm{~h})$. The results suggested that SphK1 induced, whereas SphK1 ${ }^{\mathrm{G} 82 \mathrm{D}}$ repressed cell proliferation at 48 and $72 \mathrm{~h}$ (Fig. 3C). BrdU staining was used to verify these results. The BrdU staining results revealed that overexpression of SphK1 induced proliferation in A549 cells, and overexpression of SphK $1^{\mathrm{G} 82 \mathrm{D}}$ reduced cell proliferation compared with the control cells (Fig. 3D and E). The colony formation assay was also conducted to study the cell proliferation; the results demonstrated that SphK1 increased, whereas SphK1 $1^{\mathrm{G} 82 \mathrm{D}}$ impaired the colony formation ability of A549 cells compared with the control, which was similar to the MTT and BrdU assay results (Fig. 3F and G).

SphK1 modulates the expression of the apoptosis-related genes. To determine the mechanism underlying the SphK1-mediated increase in A549 proliferation, the 



Figure 1. mRNA and protein expression levels of SphK1 and SphK2 in NSCLC and SCLC tissues. (A and B) mRNA expression levels of (A) SphK1 and (B) SphK2 in NSCLC samples were higher compared with normal lung tissues. (C and D) mRNA expression levels of (C) SphK1 and (D) SphK2 in SCLC samples were higher compared with normal lung tissues. (E and F) Protein expression levels of SphK1 and SphK2 in NSCLC samples were higher compared with normal lung tissues. (G and H) Protein expression levels of SphK1 and SphK2 in SCLC samples were higher compared with normal lung tissues. "P<0.05, ${ }^{* *} \mathrm{P}<0.01$ vs. Ctrl. SphK, sphingosine kinase; SCLC, small cell lung cancer; NSCLC, non-small cell lung cancer; Ctrl, normal lung tissues.

expression levels of apoptosis-associated genes Bcl-2, Bcl-xL and cyclin D1, which are required for maintenance of proliferation of cancer cells and tumorigenesis, were assessed after transfection of SphK1 or SphK1 ${ }^{\mathrm{G} 82 \mathrm{D}}$. The mRNA expression levels of the antiapoptotic genes were increased in the SphK1 overexpression group compared with the control cells. SphK $1^{\mathrm{G} 82 \mathrm{D}}$ overexpression resulted in a decrease in mRNA expression levels of these genes compared with the control 

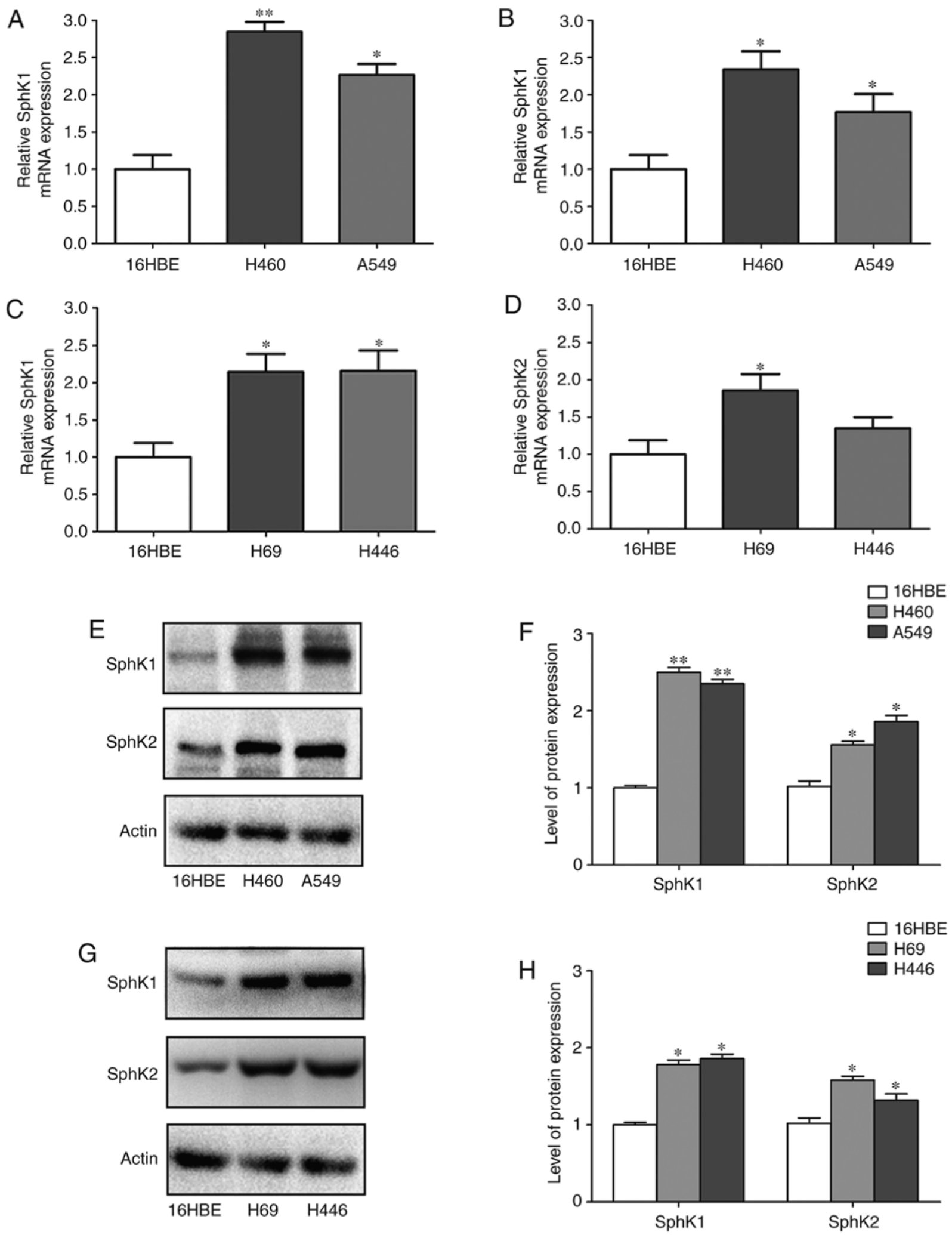

Figure 2. mRNA and protein expression levels of SphK1 and SphK2 in NSCLC and SCLC cell lines. (A and B) mRNA expression levels of (A) SphK1 and (B) SphK2 in the NSCLC cell lines were higher compared with the normal lung cell line 16HBE. (C) mRNA expression levels of SphK1 in the SCLC cell lines were higher compared with the normal lung cells. (D) mRNA expression levels of SphK2 were higher in A549, H460 and H69 cells compared with the normal lung cells. (E and F) Protein expression levels of SphK1 and SphK2 in the NSCLC cell lines were higher compared with the normal lung cells. (G and H) Protein expression levels of SphK1 and SphK2 in the SCLC cell lines were higher compared with the normal lung cells. ${ }^{*} \mathrm{P}<0.05$, ${ }^{* *} \mathrm{P}<0.01$ vs. 16HBE. SphK, sphingosine kinase; SCLC, small cell lung cancer; NSCLC, non-small cell lung cancer; Ctrl, normal lung tissues.

cells (Fig. 4A). Additionally, the protein expression levels of these factors were assessed, and the results were similar to the mRNA results (Fig. 4B and C). These results suggested that SphK1 may promote the proliferation of NSCLC cells at least partly by upregulating the mRNA and protein expression levels of Bcl-2, Bcl-xL and cyclin D1. 
A



$\mathrm{B}$

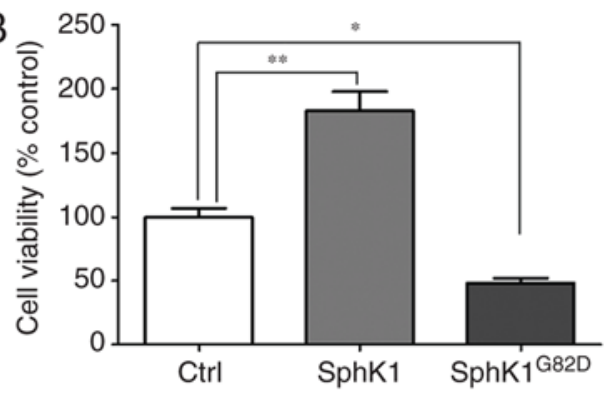

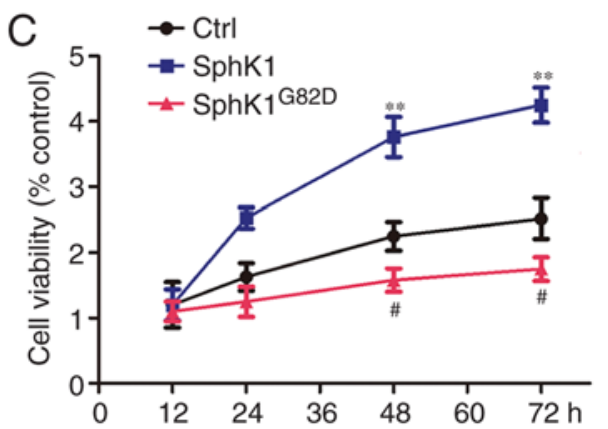
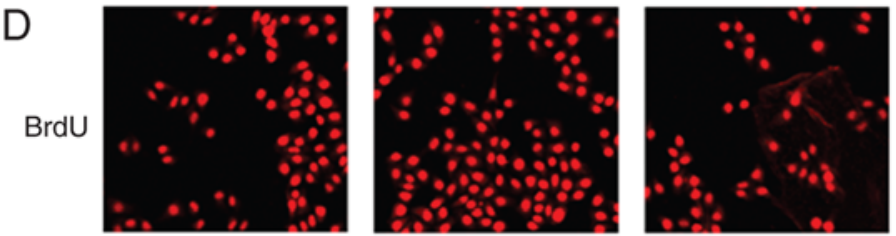

DAPI



Ctrl

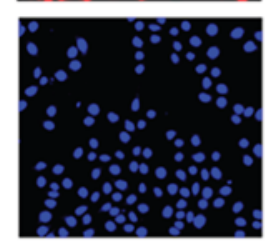

SphK1



SphK1 ${ }^{\mathrm{G} 82 \mathrm{D}}$

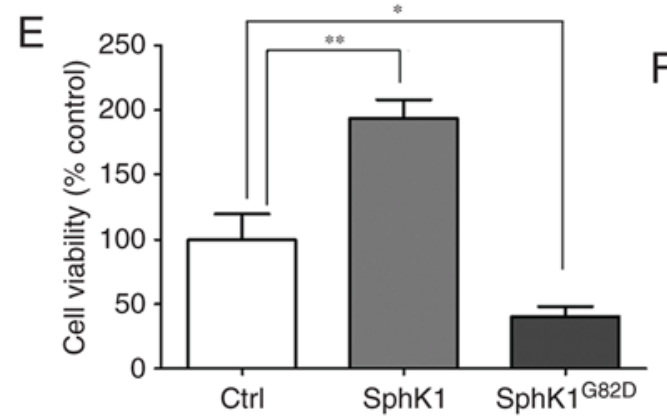

$\mathrm{F}$



Ctrl



SphK1

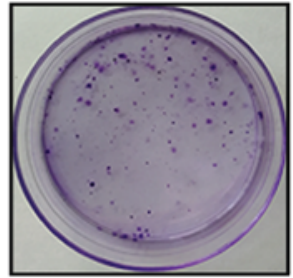

SphK $1^{\mathrm{G} 82 \mathrm{D}}$

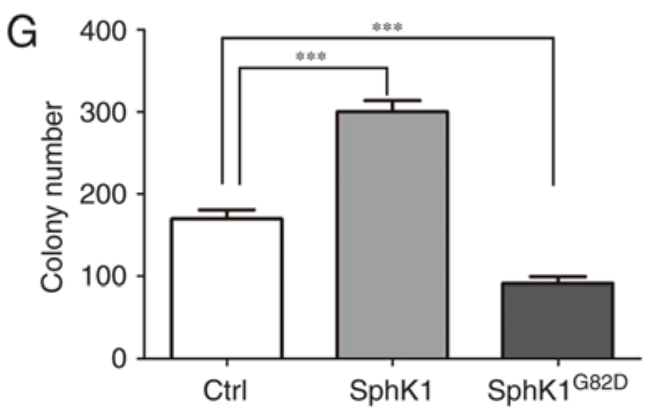

Figure 3. SphK1 promotes the proliferation of NSCLC cells. (A) Verification of successful transfection of the SphK1 overexpression vectors in A549 cells. (B) Overexpression of SphK1 increased the proliferation, whereas transfection with SphK1 ${ }^{\mathrm{G} 82 \mathrm{D}}$ reduced the proliferation of A549 cells compared with the control. (C) Cell viability at different time points following transfection with SphK1 and SphK1 ${ }^{\mathrm{G} 82 \mathrm{D}}$. ${ }^{* *} \mathrm{P}<0.01$, SphK1 group vs. control group; ${ }^{\# \#} \mathrm{P}<0.01$, SphK1 ${ }^{\mathrm{G} 82 \mathrm{D}}$ group vs. control group. (D) The viability of A549 cells was assessed using a BrdU staining assay; SphK1 overexpression increased cell viability, whereas SphK1 ${ }^{\mathrm{G} 82 \mathrm{D}}$ reduced it compared with the control. (E) The viability of cells increased in the SphK1-transfected cells, but decreased in SphK1 ${ }^{\mathrm{G} 82 \mathrm{D}}$-transfected cells compared with the control. (F) The colony formation assay of A549 cells following transfection with SphK1 and SphK1 $1^{\mathrm{G} 22 \mathrm{D}}$. (G) The colony numbers increased in the SphK1-transfected cells, but decreased in SphK1 ${ }^{\mathrm{G} 82 \mathrm{D}}$-transfected cells compared with the control. ${ }^{*} \mathrm{P}<0.05,{ }^{* * *} \mathrm{P}<0.01,{ }^{* * * *} \mathrm{P}<0.001$. SphK, sphingosine kinase; NSCLC, non-small cell lung cancer; Ctrl, control.

SphK1 promotes the invasion of NSCLC cells by modulating metastasis-associated genes. To further elucidate the roles of SphK1 in NSCLC, SphK1 and SphK1 ${ }^{\mathrm{G} 82 \mathrm{D}}$ were overexpressed in A549 cells, and the invasive capacity of these cells was assessed. The Transwell invasion assay results revealed that transfection with SphK1 increased the cell invasive capacity compared with that of the control group. Overexpression of SphK $1^{\mathrm{G} 82 \mathrm{D}}$ decreased the invasive capacity of A549 cells compared with the control group (Fig. 5A and B). E-cadherin and MMP2 have been reported to be involved in the invasion and metastasis of multiple types of cancer cells (31). To further examine the role of SphK1 in NSCLC, the mRNA levels of these 
A

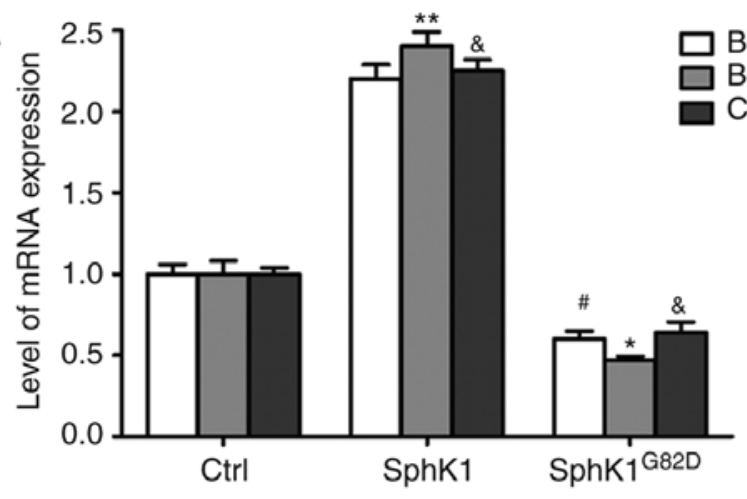

B

Bcl-xL

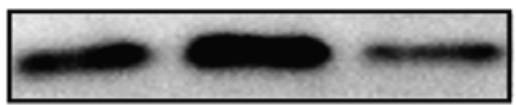

Bcl-2

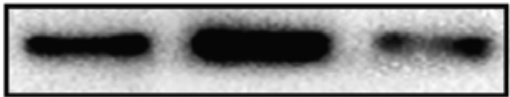

Cyclin D1



$\beta$-actin

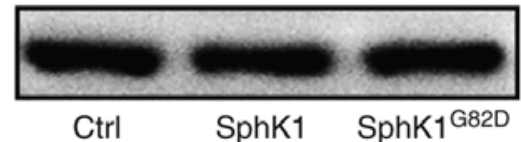

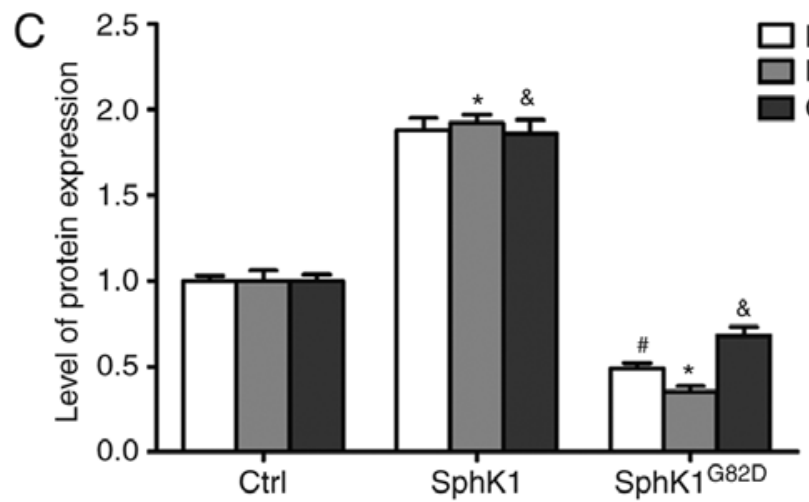

Figure 4. SphK1 modulates the expression of the apoptosis-related genes. (A) Compared with the control, the mRNA expression levels of Bcl-xL, Bcl-2 and cyclin D were increased following overexpression of SphK1, but were decreased in cells transfected with SphK1 ${ }^{\mathrm{G} 82 \mathrm{D}}$. (B and C) Protein expression levels of Bcl-2, Bcl-xL and cyclin D were increased following transfection with SphK1, but were decreased in cells transfected with SphK1 ${ }^{\mathrm{G} 82 \mathrm{D}}$ compared with the control. " $\mathrm{P}<0.05,{ }^{* *} \mathrm{P}<0.01$ vs. Ctrl Bcl-2; ${ }^{*} \mathrm{P}<0.05$ vs. Ctrl Bcl-xL; ${ }^{\&} \mathrm{P}<0.05$ vs. Ctrl cyclin D. SphK1, sphingosine kinase $1 ;$ Ctrl, control.

A
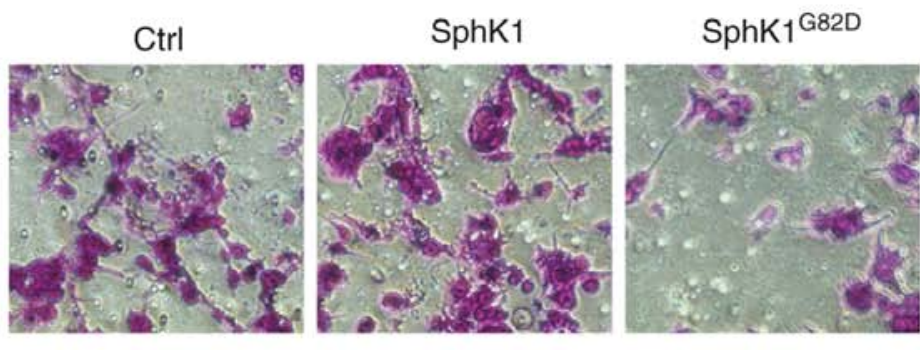

$\mathrm{B}$

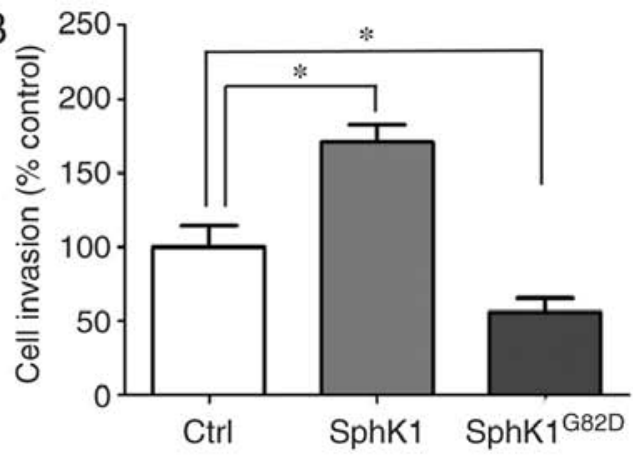

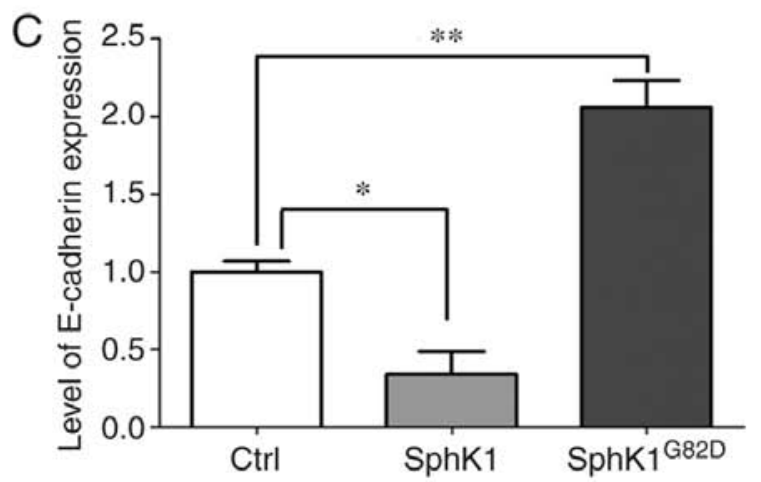

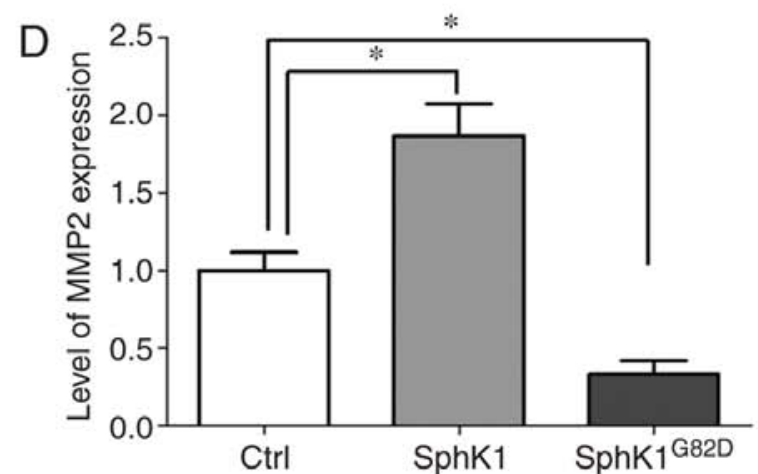

Figure 5. SphK1 promotes the invasion of NSCLC cells. (A) Compared with the control cells, SphK1 overexpression increased the number of invasive cells, whereas transfection with SphK1 $1^{\mathrm{G} 82 \mathrm{D}}$ reduced it. (B) The invasive capacity of the SphK1-transfected cells was increased, whereas in the SphK1 ${ }^{\mathrm{G} 82 \mathrm{D}}$-transfected cells, it was decreased compared with the control. (C) mRNA expression levels of E-cadherin were decreased in the SphK1-transfected cells and increased in the SphK1 $1^{\mathrm{G} 82 \mathrm{D}}$-transfected cells compared with the control. (D) mRNA expression levels of MMP2 were increased in the SphK1-transfected cells and decreased in the SphK1 ${ }^{\mathrm{G} 82 \mathrm{D}}$-transfected cells compared with the control. ${ }^{*} \mathrm{P}<0.05,{ }^{* *} \mathrm{P}<0.01$. SphK1, sphingosine kinase 1; NSCLC, non-small cell lung cancer; MMP, matrix metalloproteinase; Ctrl, control. 
A
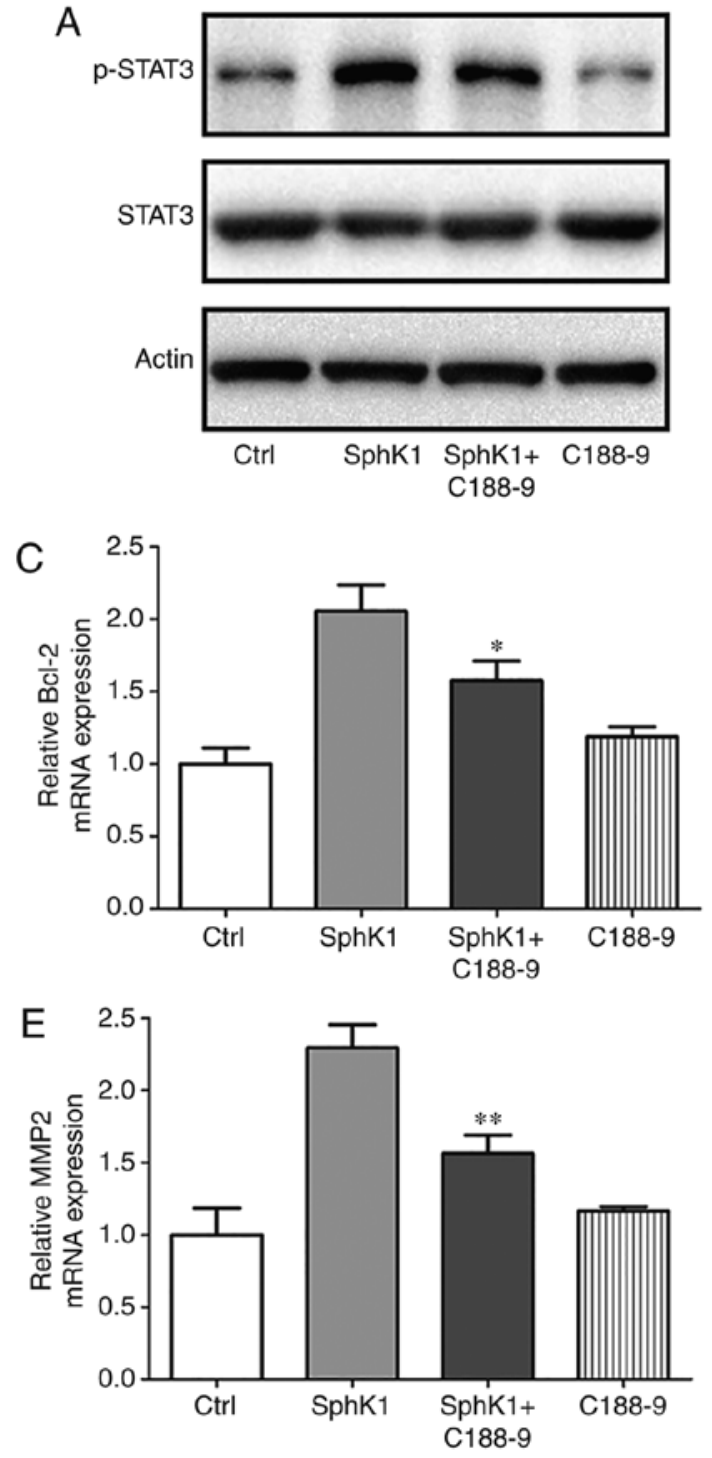

B
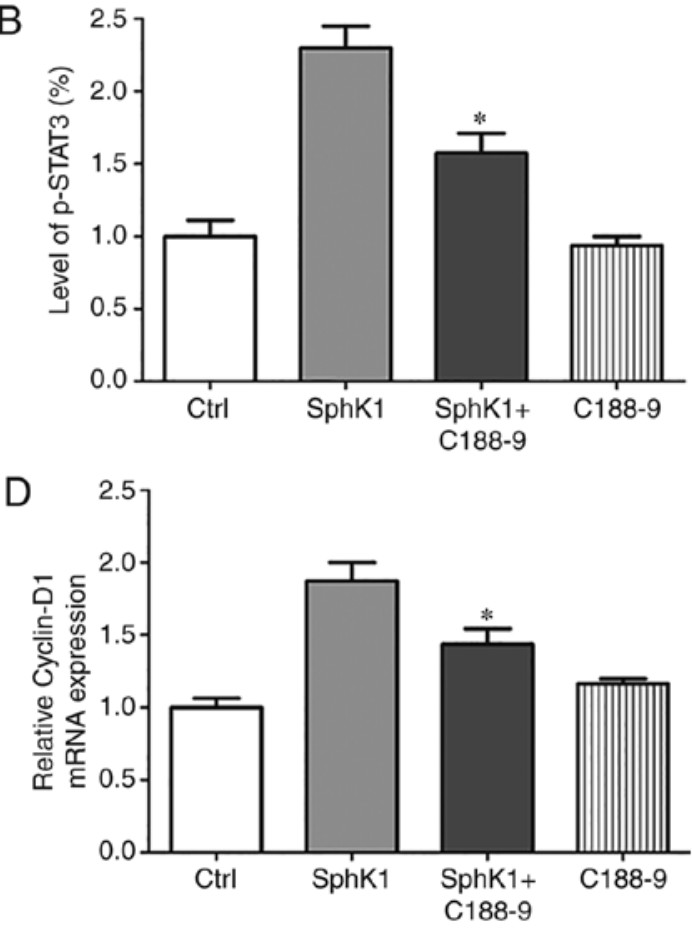

$\mathrm{F}$



G


Figure 6. SphK1 regulates the proliferation and invasion of A549 cells by activating STAT3. (A and B) SphK1 overexpression induced the activation of STAT3, whereas SphK1 ${ }^{\mathrm{G} 82 \mathrm{D}}$ transfection attenuated the activation of STAT3 compared with the control. (C-E) A549 cells were treated with C188-9 (STAT3 inhibitor) following transfection with SphK1. mRNA expression levels of (C) Bcl-2, (D) cyclin D1 and (E) MMP2 were increased after transfection with SphK1 compared with the control cells, and treatment with C188-9 reversed the increase in Bcl-2, cyclin D1 and MMP2 mRNA levels. (F) Transfection with SphK1 increased cell viability compared with the control, whereas treatment with C188-9 reversed this effect. (G and H) Transfection with SphK1 increased the invasive capacity of A549 cells compared with the control cells, whereas treatment with C188-9 reversed the SphK1-induced increase. ${ }^{*} \mathrm{P}<0.05,{ }^{* *} \mathrm{P}<0.01$. SphK, sphingosine kinase; MMP, matrix metalloproteinase STAT3, signal transducer and activator of transcription 3; Ctrl, control. 




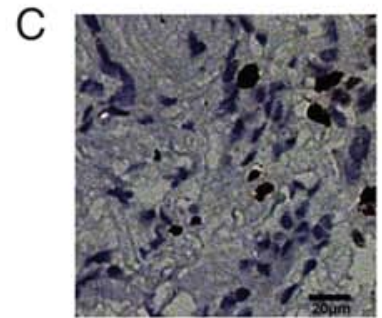

Ctrl

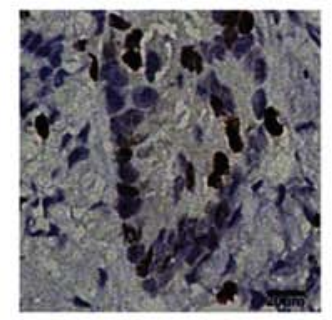

SphK1+C188-9



SphK1



C188-9
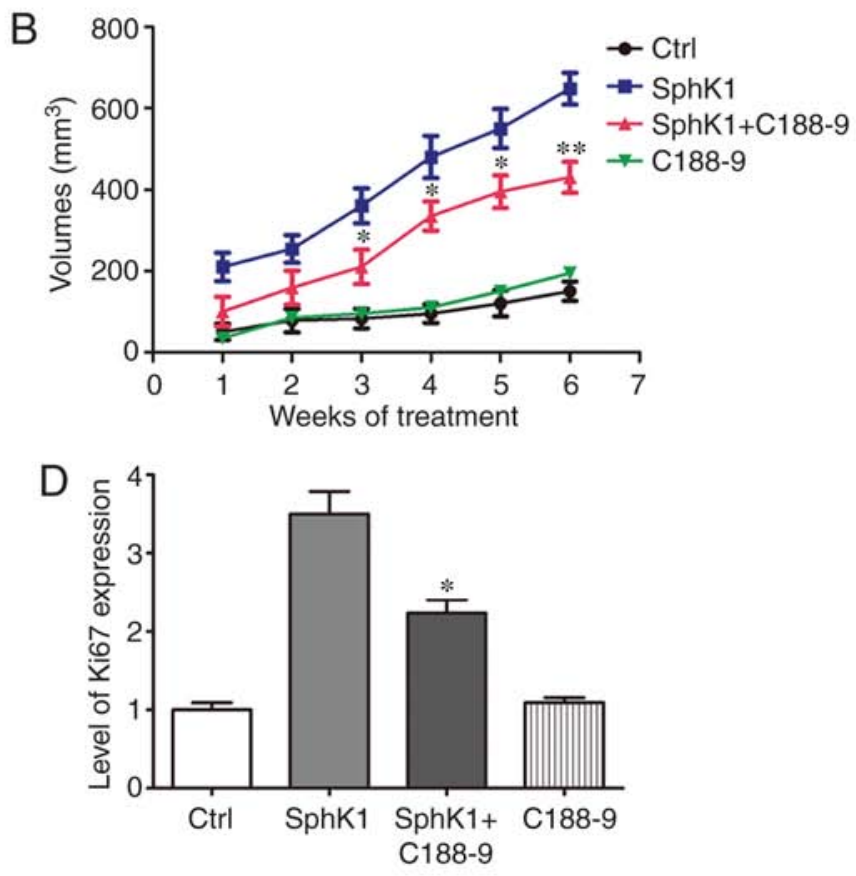

Figure 7. SphK1 promotes NSCLC progression in vivo by activating STAT3. (A and B) Overexpression of SphK1 increased the tumor size in the xenograft lung model compared with the control group, whereas treatment with the STAT3 inhibitor C188-9 reversed this effect. (C and D) Ki67 was highly expressed in the SphK1 tumors and treatment with the STAT3 inhibitor reduced the SphK1-induced increase in Ki67 expression levels. " $\mathrm{P}<0.05{ }^{* *} \mathrm{P}<0.01$. SphK1, sphingosine kinase 1; NSCLC, non-small cell lung cancer; STAT3, signal transducer and activator of transcription 3; Ctrl, control.

two genes were determined. The mRNA expression levels of E-cadherin were decreased in the SphK1-transfected cells and increased in the SphK $1^{\mathrm{G} 82 \mathrm{D}}$-transfected cells compared with the control cells (Fig. 5C). By contrast, the mRNA expression levels of MMP2 were upregulated following transfection with SphK1 and downregulated in the SphK1 $1^{\mathrm{G} 82 \mathrm{D}}$-overexpressing cells compared with the control cells (Fig. 5D).

SphK1 expression increases STAT3 activity in NSCLC cells. STAT3 has been reported to be a master regulator of cell proliferation, metastasis, immune evasion and EMT (32). Thus, it was determined whether STAT3 was activated by SphK1 overexpression. The western blotting results demonstrated that compared with those in the control cells, SphK1 overexpression resulted in an increase in p-STAT3 levels, indicative of STAT3 activation. By contrast, treatment with the SphK1 inhibitor C188-9 attenuated the activation of STAT3 (Fig. 6A and B). To determine whether SphK1 regulated the proliferation and invasion of A549 cells through the activation of STAT3, A549 cells were treated with the STAT3 inhibitor, C188-9, after transfection with SphK1. Subsequently, the mRNA expression levels of apoptosis- and metastasis-associated genes were assessed. The results demonstrated that the SphK1-induced upregulation of Bcl-2, cyclin D1 and MMP2 mRNA expression levels were reversed by the STAT3 inhibitor C188-9, whereas treatment with C188-9 exhibited a less prominent effect on the expression of the aforementioned genes in the control cells (Fig. 6C-E). MTT and Transwell invasion assays were performed to examine the role of C188-9 on SphK1-overexpressing cells. The results revealed that overexpression of SphK1 increased the proliferation and invasion of A549 cells compared with the control group, and treatment with C188-9 significantly suppressed the SphK1-enhanced proliferation and invasion (Fig. 6F-H). Together, these results suggested that SphK1 promoted the progression of NSCLC by activating STAT3.

SphK1 promotes NSCLC progression in vivo by activating STAT3. To further evaluate the effects of SphK1 on tumorigenesis and explore the underlying mechanism, A549 cells stably overexpressing SphK1 were used to establish a xenograft lung cancer model in nude mice (Fig. S2). The results demonstrated that overexpression of SphK1 resulted in a significant increase in tumor size compared with the control group; however, treatment with C188-9 reversed the SphK1-induced increase in tumor size (Fig. 7A and B). Ki67 expression was analyzed in these tumor samples as an indicator of proliferation in the tumor. The immunohistochemistry results revealed that Ki67 was highly expressed in the SphK1 group, and the STAT3 inhibitor reduced the SphK1-induced increase in Ki67 levels (Fig. 7C and D). Together, these results suggested that SphK1 promoted tumor growth through activation of STAT3 in vivo. 


\section{Discussion}

Despite notable advances in our understanding of lung cancer, the underlying mechanisms remain to be completely elucidated. SphK1 is an oncogenic enzyme that participates in cell proliferation, migration and invasion (33). Upregulated expression of SphK1 has been observed in gastric, breast and colorectal cancer (34-36). In addition, SphK1 was reported to be highly expressed in NSCLC cell lines (37). High levels of SphK1 are associated with tumor progression and unfavorable outcomes in patients with NSCLC (12). In the present study, the expression of SphK1 in NSCLC cell lines and tissues was assessed, and the results demonstrated that both mRNA and protein expression levels of SphK1 were increased in NSCLC compared with the control cells and tissues. These results were consistent with previous studies $(38,39)$. Additionally, overexpression of SphK1 promoted the proliferation and metastasis of NSCLC cells, whereas inhibition of SphK1 catalytic activity (overexpression of SphK $1^{\text {G82D }}$ ) had the opposite effects. The results of the present study were consistent with a previous study (40).

SphK1 has been demonstrated to modulate the expression of EMT-associated genes, promoting the migratory and metastatic capacity of cancer cells (41). SphK1 also promoted autophagy and accelerated lysosomal degradation of CDH1/E-cadherin to induce EMT in hepatoma cells (12). In addition, SphK1 increased the resistance of breast cancer cells to chemotherapeutic agents and radiotherapy (42). In the present study, overexpression of SphK1 increased the expression of antiapoptotic and metastasis-associated genes cyclin D1, MMP2 and Bcl-2. These target genes have been demonstrated to affect tumor progression in gastric and renal cell carcinoma $(43,44)$. The results of the present study provided novel evidence demonstrating the role of SphK1 in cancer development.

Expression of STAT3 has been estimated to be aberrantly increased in $>70 \%$ of the different types of cancer, including acute myeloid leukemia, bone, breast cancer and solid tumors of the bladder $(19,45)$. Modulating the function or expression of STAT3 has demonstrated the importance of STAT3 in the development of different types of cancer (46). STAT3 is typically involved in the regulation of cell proliferation, immunosuppression and apoptosis resistance (47). As a transcription factor, STAT3 is hypothesized to function by inducing the expression of its target genes; for example, STAT3 affects cell proliferation by modulating transcription of Bcl-xL, cyclin D1 or MYC $(48,49)$. Through modulation of the expression of vascular endothelial growth factor receptor, STAT3 regulates angiogenesis (50). In osteosarcoma, STAT3 regulates the transcription of serine/threonine kinase 35, which results in increased proliferation and reduced apoptosis of osteosarcoma cells (51). In breast cancer, STAT3 cross-talks with the NF- $\mathrm{KB}$ signaling pathway by targeting the tumor necrosis factor receptor superfamily member $1 \mathrm{~A}$ to induce cancer development (19). Small-molecule STAT3 inhibitors have been reported to induce apoptosis in acute myeloid leukemia (46). In NSCLC, STAT3 promotes metastasis via aldo-keto reductase family 1 member $\mathrm{C} 1$ (52). In the present study, STAT3 was activated in A549 cells overexpressing SphK1, and overexpression of SphK1 ${ }^{\mathrm{G} 82 \mathrm{D}}$ resulted in reduced STAT3 activity.
SphK1 has been demonstrated to modulate and to be modulated by multiple signaling pathways. SphK1 activates the PI3K/Akt/NF- $\mathrm{KB}$ pathway in NSCLC to enhance cell viability (24). By compromising protein kinase $\mathrm{C}$ activity, SphK1 has been demonstrated to induce the proliferation and survival in breast, lung and colon carcinoma cells (53-55). S1P, the product of SphK1, is an important factor involved in the activation of STAT3 in cancer cells (56). However, the association between SphK1 and STAT3 remains to be elucidated in NSCLC. To address this gap in our knowledge, A549 cells where treated with STAT3 inhibitor following transfection of SphK1 in the present study. The results revealed that overexpression of SphK1 activated STAT3 compared with the control cells, whereas inhibition of STAT3 reduced the antiapoptotic role of SphK1 by disturbing the regulation of target genes.

However, the means by which SphK1 regulates expression of STAT3 remains unknown. A previous study has demonstrated that the activation of SphK1 results in increased production of S1P, which in turn increases the expression of IL-6 and subsequent activation of STAT3 in colitis-associated cancer (18). In dystrophic muscles, S1P activates STAT3 by inhibiting Rho GTPase Rac1 in a S1P receptor 2 (S1PR2)-dependent manner (57). Although it has been reported high SphK1 expression is associated with poor overall survival and acts as a prognosis predictor in NSCLC (56), the results of the present study further confirmed that SphK1 affected the NSCLC cell proliferation and invasion by modulating apoptosisand metastasis-associated genes Bcl-2, Bcl-xL, cyclin D1, E-cadherin and MMP2. The signaling pathways regulated by SphK1 have also been investigated in multiple types of cancer. For example, STAT3 was revealed to be targeted by SphK1 in colorectal cancer, neuroblastoma, colitis-associated cancer and hepatocellular carcinoma (58). However, whether SphK1 regulates the expression of STAT3 has not been reported. It also remains to be explored whether this pathway may promote tumorigenesis in NSCLC. The present study demonstrated that SphK1 modulated the activation of STAT3 in NSCLC. In addition, SphK1 promoted the NSCLC development via the STAT3 pathway in vitro and in vivo. Inhibiting STAT3 may be a potential strategy to compromise the oncogenic role of SphK1 in NSCLC.

In summary, increased expression of SphK1 was observed in NSCLC tissues and cells compared with control tissues and normal lung cells, respectively, and potential target genes were identified, which may account for the oncogenic effects of SphK1. Additionally, an SphK1-STAT3 axis was identified as a novel mechanism underlying the progression of NSCLC. The results of the present study suggested that inhibition of the SphK1-STAT3 axis may represent a potential strategy for treatment of patients with NSCLC.

\section{Acknowledgements}

Not applicable.

\section{Funding}

The present study was supported by the Key Research and Development Plan Project of Shaanxi Province (grant no. 2019SF-221; Henan, China). 


\section{Availability of data and materials}

The datasets used and/or analyzed during the present study are available from the corresponding author on reasonable request.

\section{Authors' contributions}

GC and YM designed the study. YM, XX and RK performed the experiments. CC, SuL and ShL performed the statistical analysis. YM, XX, XY and LS validated the data. GC, FZ and YM analyzed the data. XX and YM performed the experiments. GC curated the data. YM, XX and GC wrote and revised the manuscript. YM, XX, RK and CC produced the graphs. GC supervised the study. All authors read and approved the final manuscript.

\section{Ethics approval and consent to participate}

All mouse experiments were approved by The Institutional Animal Care and Use Committee of The First Affiliated Hospital of Xi'an Jiaotong University (Xi'an, China). All procedures performed on patient tissues in the present study were approved by the Research Ethics Committee of The First Affiliated Hospital of Xi'an Jiaotong University, and written informed consent was obtained from all patients.

\section{Patient consent for publication}

Not applicable.

\section{Competing interests}

The authors declare that they have no competing interests.

\section{References}

1. Siegel R, Ma J, Zou Z and Jemal A: Cancer statistics, 2014. CA Cancer J Clin 64: 9-29, 2014

2. Zheng H, Zhan Y, Liu S, Lu J, Luo J, Feng J and Fan S: The roles of tumor-derived exosomes in non-small cell lung cancer and their clinical implications. J Exp Clin Cancer Res 37: 226, 2018.

3. Hirsch FR, Suda K, Wiens J and Bunn PA Jr: New and emerging targeted treatments in advanced non-small-cell lung cancer. Lancet 388: 1012-1024, 2016

4. Zhu L, Wang Z, Lin Y, Chen Z, Liu H, Chen Y, Wang N and Song $X$ : Sphingosine kinase 1 enhances the invasion and migration of non-small cell lung cancer cells via the AKT pathway. Oncol Rep 33: 1257-1263, 2015.

5. Maceyka M, Sankala H, Hait NC, Le Stunff H, Liu H, Toman R, Collier C, Zhang M, Satin LS, Merrill AH Jr, et al: SphK1 and SphK2, sphingosine kinase isoenzymes with opposing functions in sphingolipid metabolism. J Biol Chem 280: 37118-37129, 2005.

6. Adams DR, Pyne S and Pyne NJ: Sphingosine kinases: Emerging structure-function insights. Trends Biochem Sci 41: 395-409, 2016.

7. Meacci E and Garcia-Gil M: S1P/S1P receptor signaling in neuromuscolar disorders. Int J Mol Sci 20: E6364, 2019.

8. Sukocheva OA, Furuya H, Ng ML, Friedemann M, Menschikowski M, Tarasov VV, Chubarev VN, Klochkov SG, Neganova ME, Mangoni AA, et al: Sphingosine kinase and sphingosine-1-phosphate receptor signaling pathway in inflammatory gastrointestinal disease and cancers: A novel therapeutic target. Pharmacol Ther 207: 107464, 2020.

9. Andrieu G, Ledoux A, Branka S, Bocquet M, Gilhodes J, Walzer T, Kasahara K, Inagaki M, Sabbadini RA, Cuvillier O and Hatzoglou A: Sphingosine 1-phosphate signaling through its receptor $\mathrm{S}_{1} \mathrm{P}_{5}$ promotes chromosome segregation and mitotic progression. Sci Signal 10: eaah4007, 2017.
10. Lee CF, Dang A, Hernandez E, Pong RC, Chen B, Sonavane R, Raj G, Kapur P, Lin HY, Wu SR, et al: Activation of sphingosine kinase by lipopolysaccharide promotes prostate cancer cell invasion and metastasis via SphK1/S1PR4/matriptase. Oncogene 38: 5580-5598, 2019.

11. Zheng X, Li W, Ren L, Liu J, Pang X, Chen X, Kang, Wang J and Du G: The sphingosine kinase-1/sphingosine-1-phosphate axis in cancer: Potential target for anticancer therapy. Pharmacol Ther 195: 85-99, 2019.

12. Liu H, Ma Y, He HW, Zhao WL and Shao RG: SPHK1 (sphingosine kinase 1) induces epithelial-mesenchymal transition by promoting the autophagy-linked lysosomal degradation of CDH1/E-cadherin in hepatoma cells. Autophagy 13: 900-913, 2017.

13. Hillmer EJ, Zhang H, Li HS and Watowich SS: STAT3 signaling in immunity. Cytokine Growth Factor Rev 31: 1-15, 2016.

14. Galoczova M, Coates P and Vojtesek B: STAT3, stem cells, cancer stem cells and p63. Cell Mol Biol Lett 23: 12, 2018.

15. Johnson DE, O'Keefe RA and Grandis JR: Targeting the IL-6/JAK/STAT3 signalling axis in cancer. Nat Rev Clin Oncol 15: 234-248, 2018.

16. Wang Y, van Boxel-Dezaire AH, Cheon H, Yang J and Stark GR: STAT3 activation in response to IL- 6 is prolonged by the binding of IL-6 receptor to EGF receptor. Proc Natl Acad Sci USA 110: 16975-16980, 2013.

17. Zhao D, Pan C, Sun J, Gilbert C, Drews-Elger K, Azzam DJ, Picon-Ruiz M, Kim M, Ullmer W, El-Ashry D, et al: VEGF drives cancer-initiating stem cells through VEGFR-2/Stat3 signaling to upregulate Myc and Sox2. Oncogene 34: 3107-3119, 2015.

18. Liang J, Nagahashi M, Kim EY, Harikumar KB, Yamada A, Huang WC, Hait NC, Allegood JC, Price MM, Avni D, et al: Sphingosine-1-phosphate links persistent STAT3 activation, chronic intestinal inflammation, and development of colitis-associated cancer. Cancer Cell 23: 107-120, 2013.

19. Egusquiaguirre SP, Yeh JE, Walker SR, Liu S and Frank DA: The STAT3 target gene TNFRSF1A modulates the NF- $\kappa$ B pathway in breast cancer cells. Neoplasia 20: 489-498, 2018.

20. Horibata S, Rice EJ, Zheng H, Mukai C, Chu T, Marks BA, Coonrod SA and Danko CG: A bi-stable feedback loop between GDNF, EGR1, and ER $\alpha$ contribute to endocrine resistant breast cancer. PLoS One 13: e0194522, 2018.

21. Masuda M, Suzui M, Yasumatu R, Nakashima T, Kuratomi Y, Azuma K, Tomita K, Komiyama S and Weinstein IB: Constitutive activation of signal transducers and activators of transcription 3 correlates with cyclin D1 overexpression and may provide a novel prognostic marker in head and neck squamous cell carcinoma. Cancer Res 62: 3351-3355, 2002.

22. Xu L, Wang P, Feng X, Tang J, Li L, Zheng X, Zhang J, $\mathrm{Hu}$ Y, Lan T, Yuan K, et al: SETD3 is regulated by a couple of microRNAs and plays opposing roles in proliferation and metastasis of hepatocellular carcinoma. Clin Sci (Lond) 133: 2085-2105, 2019.

23. Merino D, Lok SW, Visvader JE and Lindeman GJ: Targeting BCL-2 to enhance vulnerability to therapy in estrogen receptor-positive breast cancer. Oncogene 35: 1877-1887, 2016.

24. Liu L, Zhou XY, Zhang JQ, Wang GG, He J, Chen YY, Huang C, $\mathrm{Li}$ L and Li SQ: LncRNA HULC promotes non-small cell lung cancer cell proliferation and inhibits the apoptosis by up-regulating sphingosine kinase 1 (SPHK1) and its downstream PI3K/Akt pathway. Eur Rev Med Pharmacol Sci 22: 8722-8730, 2018.

25. Fan Z, Jiang H, Wang Z and Qu J: Atorvastatin partially inhibits the epithelial-mesenchymal transition in A549 cells induced by TGF- $\beta 1$ by attenuating the upregulation of SphK1. Oncol Rep 36: 1016-1022, 2016.

26. Schwartz LH, Seymour L, Litiere S, Ford R, Gwyther S, Mandrekar S, Shankar L, Bogaerts J, Chen A, Dancey J, et al: RECIST 1.1 Standardisation and disease-specific adaptations: Perspectives from the RECIST working group. Eur J Cancer 62: 138-145, 2016.

27. Livak KJ and Schmittgen TD: Analysis of relative gene expression data using real-time quantitative PCR and the 2(-Delta Delta $\mathrm{C}(\mathrm{T})$ ) method. Methods 25: 402-408, 2001.

28. Tang Z, Kang B, Li C, Chen T and Zhang Z: GEPIA2: An enhanced web server for large-scale expression profiling and interactive analysis. Nucleic Acids Res 47(W1): W556-W560, 2019.

29. Lan T, Liu W, Xie X, Xu S, Huang K, Peng J, Shen X, Liu P, Wang L, Xia P and Huang H: Sphingosine kinase-1 pathway mediates high glucose-induced fibronectin expression in glomerular mesangial cells. Mol Endocrinol 25: 2094-2105, 2011. 
30. Chen J, Tang H, Sysol JR, Moreno-Vinasco L, Shioura KM, Chen T, Gorshkova I, Wang L, Huang LS, Usatyuk PV, et al: The sphingosine kinase 1/sphingosine-1-phosphate pathway in pulmonary arterial hypertension. Am J Respir Crit Care Med 190: 1032-1043, 2014.

31. Hardy E, Hardy-Sosa A and Fernandez-Patron C: MMP-2: Is too low as bad as too high in the cardiovascular system? Am J Physiol Heart Circ Physiol 315: H1332-H1340, 2018.

32. Lo UG, Bao J, Cen J, Yeh HC, Luo J, Tan W and Hsieh JT: Interferon-induced IFIT5 promotes epithelial-to-mesenchymal transition leading to renal cancer invasion. Am J Clin Exp Urol 7: 31-45, 2019 eCollection 2019.

33. Wu X, Wu Q, Zhou X and Huang J: SphK1 functions downstream of IGF-1 to modulate IGF-1-induced EMT, migration and paclitaxel resistance of A549 cells: A preliminary in vitro study. J Cancer 10: 4264-4269, 2019.

34. Yin S, Miao Z, Tan Y, Wang P, Xu X, Zhang C, Hou W, Huang J and $\mathrm{Xu} \mathrm{H}$ : SPHK1-induced autophagy in peritoneal mesothelial cell enhances gastric cancer peritoneal dissemination. Cancer Med 8: 1731-1743, 2019.

35. Acharya S, Yao J, Li P, Zhang C, Lowery FJ, Zhang Q, Guo H, Qu J, Yang F, Wistuba II, et al: Sphingosine kinase 1 signaling promotes metastasis of triple-negative breast cancer. Cancer Res 79: 4211-4226, 2019.

36. Shen Z, Feng X, Fang Y, Li Y, Li Z, Zhan Y, Lin M, Li G, Ding Y and Deng H: POTEE drives colorectal cancer development via regulating SPHK1/p65 signaling. Cell Death Dis 10: 863, 2019.

37. Song L, Xiong H, Li J, Liao W, Wang L, Wu J and Li M: Sphingosine kinase-1 enhances resistance to apoptosis through activation of $\mathrm{PI} 3 \mathrm{~K} / \mathrm{Akt} / \mathrm{NF}-\kappa \mathrm{B}$ pathway in human non-small cell lung cancer. Clin Cancer Res 17: 1839-1849, 2011.

38. Yang L, Hu H, Deng Y and Bai Y: Role of SPHK1 regulates multi-drug resistance of small cell lung cancer and its clinical significance. Zhongguo Fei Ai Za Zhi 17: 769-777, 2014 (In Chinese).

39. Zhang G, Zheng H, Zhang G, Cheng R, Lu C, Guo Y and Zhao G: MicroRNA-338-3p suppresses cell proliferation and induces apoptosis of non-small-cell lung cancer by targeting sphingosine kinase 2. Cancer Cell Int 17: 46, 2017.

40. Li Y, Hu T, Chen T, Yang T, Ren H and Chen M: Combination treatment of FTY720 and cisplatin exhibits enhanced antitumour effects on cisplatin-resistant non-small lung cancer cells. Oncol Rep 39: 565-572, 2018.

41. Xu CY, Liu SQ, Qin MB, Zhuge CF, Qin L, Qin N, Lai MY and Huang JA: SphK1 modulates cell migration and EMT-related marker expression by regulating the expression of p-FAK in colorectal cancer cells. Int J Mol Med 39: 1277-1284, 2017.

42. Marvaso G, Barone A, Amodio N, Raimondi L, Agosti V, Altomare E, Scotti V, Lombardi A, Bianco R, Bianco C, et al: Sphingosine analog fingolimod (FTY720) increases radiation sensitivity of human breast cancer cells in vitro. Cancer Biol Ther 15: 797-805, 2014

43. Chen XF, Guo JF, Xu JF, Yin SH and Cao WL: MiRNA-206 inhibits proliferation of renal clear cell carcinoma by targeting ZEB2. Eur Rev Med Pharmacol Sci 23: 7826-7834, 2019.

44. Wang Z, Tang T, Wang S, Cai T, Tao H, Zhang Q, Qi S and Qi Z: Aloin inhibits the proliferation and migration of gastric cancer cells by regulating NOX2-ROS-Mediated pro-survival signal pathways. Drug Des Devel Ther 14: 145-155, 2020.
45. Zhao S, Guo J, Zhao Y, Fei C, Zheng Q, Li X and Chang C: Chidamide, a novel histone deacetylase inhibitor, inhibits the viability of MDS and AML cells by suppressing JAK2/STAT3 signaling. Am J Transl Res 8: 3169-3178, 2016.

46. Guanizo AC, Fernando CD, Garama DJ and Gough DJ: STAT3. A multifaceted oncoprotein. Growth Factors 36: 1-14, 2018.

47. Lewis KM, Bharadwaj U,Eckols TK, Kolosov M, Kasembeli MM, Fridley C, Siller R and Tweardy DJ: Small-molecule targeting of signal transducer and activator of transcription (STAT) 3 to treat non-small cell lung cancer. Lung Cancer 90: 182-190,2015.

48. Kanda N, Seno H, Konda Y, Marusawa H, Kanai M, Nakajima T, Kawashima T, Nanakin A, Sawabu T, Uenoyama Y, et al: STAT3 is constitutively activated and supports cell survival in association with survivin expression in gastric cancer cells. Oncogene 23: 4921-4929, 2004.

49. Kijima T, Niwa H, Steinman RA, Drenning SD, Gooding WE, Wentzel AL, Xi S and Grandis JR: STAT3 activation abrogates growth factor dependence and contributes to head and neck squamous cell carcinoma tumor growth in vivo. Cell Growth Differ 13: 355-362, 2002

50. Lei Z, Duan H, Zhao T, Zhang Y, Li G, Meng J, Zhang S and Yan W: PARK2 inhibits osteosarcoma cell growth through the JAK2/STAT3/VEGF signaling pathway. Cell Death Dis 9: 375, 2018.

51. Wu Z, Liu J, Hu S, Zhu Y and Li S: Serine/Threonine kinase 35 , a target gene of STAT3, regulates the proliferation and apoptosis of osteosarcoma cells. Cell Physiol Biochem 45: 808-818, 2018.

52. Zhu H, Chang LL, Yan FJ, Hu Y, Zeng CM, Zhou TY, Yuan T, Ying MD, Cao J, He QJ and Yang B: AKR1C1 activates STAT3 to promote the metastasis of non-small cell lung cancer. Theranostics 8: 676-692, 2018.

53. Nazouri AS, Asadpour O, Dabiri S, Pourseyedi B, Lashkarizadeh MR and Zianalinejad H: High expression of sphingosine kinase 1 in estrogen and progesterone receptors-negative breast cancer. Iran J Pathol 12: 218-224, 2017.

54. Sankala HM, Hait NC, Paugh SW, Shida D, Lépine S, Elmore LW, Dent P, Milstien S and Spiegel S: Involvement of sphingosine kinase 2 in p53-independent induction of $\mathrm{p} 21$ by the chemotherapeutic drug doxorubicin. Cancer Res 67: 10466-10474, 2007.

55. Liu SQ, Xu CY, Wu WH, Fu ZH, He SW, Qin MB and Huang JA: Sphingosine kinase 1 promotes the metastasis of colorectal cancer by inducing the epithelial-mesenchymal transition mediated by the FAK/AKT/MMPs axis. Int J Oncol 54: 41-52, 2019.

56. Nagahashi M, Yamada A, Katsuta E, Aoyagi T, Huang WC, Terracina KP, Hait NC, Allegood JC, Tsuchida J, Yuza K, et al: Targeting the SphK1/S1P/S1PR1 axis that links obesity, chronic inflammation, and breast cancer metastasis. Cancer Res 78: 1713-1725, 2018.

57. Loh KC, Leong WI, Carlson ME, Oskouian B, Kumar A, Fyrst H, Zhang M, Proia RL, Hoffman EP and Saba JD: Sphingosine-1-phosphate enhances satellite cell activation in dystrophic muscles through a S1PR2/STAT3 signaling pathway. PLoS One 7: e37218, 2012.

58. Jin Z, Li H, Hong X, Ying G, Lu X, Zhuang L and Wu S: TRIM14 promotes colorectal cancer cell migration and invasion through the SPHK1/STAT3 pathway. Cancer Cell Int 18: 202, 2018. 